\title{
Evaluation Biological Activities of Diphylleia grayi Extract as a Natural Cosmetic Ingredient
}

\author{
Gibok Lee*, Areum Yeom, Chang-Min Park, Min-Seok Joung, Gi Yong Lee \\ R\&D center, Hankook Cosmetics Manufacturing Co., Ltd., Seoul, Korea
}

*Corresponding author: Gibok Lee, R\&D Center, Hankook Cosmetics Manufacturing Co., Ltd., 35 Cheonggyecheon-ro, Jongnogu, Seoul 03188, Korea

Tel.: +82263600662

Fax: +82 263600683

Email: kbok1988@hkcosm.com

Received August 04, 2020

Revised August 24, 2020

Accepted September 07, 2020

Published September 30, 2020

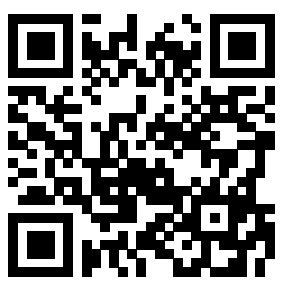

\begin{abstract}
Purpose: In this study, we investigated the biological activities of Diphylleia grayi extract as a natural cosmetic ingredient. Methods: The antioxidant activities of Diphylleia grayi extract was measured through 2,2-diphenyl-1-(2,4,6-trinitrophenyl)hydrazinyl (DPPH), 2,2'-azino-bis-3-ethylbenzthiazoline-6-sulphonic acid (ABTS) scavenging assay and Fluorescence recovery after photobleaching (FRAP) assay. We further investigated whether Diphylleia grayi extract could reduce the intracellular reactive oxygen species (ROS) using dichlorofluorescin diacetate (DCF-DA) fluorescence. To investigate the whitening effect, we conducted tyrosinase inhibition assay and L-DOPA oxidation inhibition assay. Furthermore, we performed collagenase inhibition assay to evaluate the anti-wrinkle activity of Diphylleia grayi extract. Results: Diphylleia grayi extract showed strong antioxidant activities on DPPH, ABTS radical scavenging assay. Furthermore, Diphylleia grayi extract decreased the intracellular ROS on skin normal cells. Diphylleia grayi extract has also inhibition activities of tyrosinase, L-DOPA oxidation and collagenase. Conclusion: Therefore, Diphylleia grayi extract was identified as a promising natural cosmetic ingredient which has antioxidant, whitening and anti-wrinkle properties.
\end{abstract}

Keywords: Diphylleia grayi, Reactive oxygen species, Antioxidant, Tyrosinase, Collagenase

\section{Introduction}

As the first organ that contact the external environment, skin is exposed to various aging factors including ultraviolet rays (UVR), air pollutants, heavy metals, and cigarette smoke (Krutmann et al., 2017). The prolonged continuous exposure of these exogenous factors to skin enhances the release of reactive oxygen species (ROS). Then, it trigger the activation of matrix metalloproteinases (MMPs) and inflammatory responses, hence damaging the extracellular matrix (ECM) components such as, collagen fibres and natural moisture factors (NMF) (Rinnerthaler et al., 2015). In addition, it is well studied that ROS play an important role of melanin production in human melanocyte (Denat et al., 2014). In fact, it is reported that hydrogen peroxide produced by UV irradiation, activates tyrosinase and promotes melanin synthesis in melanocyte
(Brenner \& Hearing, 2007). Although the melanin plays an essential role in protecting the skin against damaging effects of UV radiation, overproduction of melanin is sometimes regarded as considered as a metaphor of aging in Asian countries (Samson et al., 2011). Furthermore, it has been well studied that oxidative stress generated form UV light induces the expression of collagenase and elastase in skin cells, which are involved in wrinkle formation (Pittayapruek et al., 2016). Therefore, cosmetic ingredients which have ROS scavenging activities have been most commonly developed for the purpose of preventing skin aging.

Nature derived ingredients have been applied in cosmetic formulation for many years. As well as they have skin beneficial activities such as antioxidant, anti-inflammation, whitening and anti-wrinkle effects, they become one of the marketing points of some cosmetic products because of their 
unique stories (Ribeiro et al., 2015). Recently, consumers' interest in natural ingredients has increased as the risk of chemical ingredients in cosmetics has emerged. Furthermore, the concept of natural and organic cosmetics was stipulated in the Korean Cosmetics Act, increasing the need for effective functional natural materials to replace chemicals (Kim, 2020). Therefore, it is necessary to develop natural-derived cosmetic ingredients that are safe and effective against chemicals.

Diphylleia grayi is in the family Berberidaceae and it is commonly known as the skeleton flower. Usually, Diphylleia grayi has white petals, but when it rains, the color of its petals becomes translucent (Yong et al., 2015). It is native to Japan and has rarely been reported about biological effectiveness. It is reported that podophyllotoxin and diphyllin have been found in Diphylleia species and natural-derived podophyllotoxin has been reported to have anti-cancer and anti-viral efficacy (Broomhead et al., 1990). However, it has not been investigated the cosmetic effectiveness of Diphylleia grayi extract.

In this study, we firstly report the antioxidant activities of Diphylleia grayi ethanol extract. Moreover, we investigated tyrosinase, L-DOPA oxidation and collagenase inhibition activities of Diphylleia grayi ethanol extract. Through this research, we evaluated the cosmetic effectiveness of Diphylleia grayi extract.

\section{Methods}

\section{Reagents and chemicals}

2,2-Diphenyl-1-picrylhydrazyl and 2,2'-Azino-bis(3ethylbenzothiazoline-6-sulfonic acid) diammonium salt were purchased from Alfa Aesar (USA) 2',7'-dichlorofluorescin diacetate (DCF-DA), 2,2-azobis dihydrochloride(AAPH), potassium ferricyanide, $\alpha-\mathrm{MSH}$, L-Tyrosin, L-DOPA, mushroom tyrosinase, arbutin, azo dye-impregnated collagen and collagenase from Clostridium histolyticum were purchased from Sigma Aldrich (USA).

\section{Preparation Diphylleia grayi Extract}

The whole plant parts of Diphylleia grayi were dried at $45^{\circ} \mathrm{C}$ for $2 \mathrm{~h}$ in an oven and then, it were finely ground into powder. $70 \%$ ethanol was poured into the powder and incubates at 140 rpm for one day using the shacking incubator. The samples were then filtered through filter paper to separate the residue.
After that, the filtrated sample was evaporated by the vacuum rotary evaporator. Finally, Diphylleia grayi extract was obtained after freeze-drying.

\section{Cell culture and cytotoxicity of Diphylleia grayi extract}

HaCaT (human keratinocyte), HDF (human dermal fibroblast), CCD-986sk (human skin fibroblast) were cultured in Dulbecco's modified Eagle's medium (DMEM; WelGENE, Korea) supplemented with $10 \%$ fetal bovine serum (FBS) and $1 \%$ penicillin-streptomycin at $37^{\circ} \mathrm{C}$ in a $5 \% \mathrm{CO}_{2}$ incubator. Cytotoxicity of Diphylleia grayi extract was evaluated using cell proliferation kit I (Applied Science, Germany). $1 \times 10^{5}$ Cells were plated per well in 96-well plates and serial dilution samples were treated with for $48 \mathrm{~h}$. After that, add MTT in medium to a final concentration of $0.5 \mathrm{mg} / \mathrm{mL}$ and re-incubated at $37^{\circ} \mathrm{C}$. After 4h, MTT formazan was dissolved with DMSO and cell viability was measured at $540 \mathrm{~nm}$ using a microplate reader (Spectra Max, USA).

\section{DPPH radical scavenging assay}

DPPH radical scavenging assay was performed as previously described (Lee et al., 2018). $500 \mu \mathrm{L}$ of DPPH solution (0.1 $\mathrm{mM}$ ) was mixed with $500 \mu \mathrm{L}$ of the sample and incubated 30 min in dark room. The DPPH radical scavenging activity was measured at a wavelength of $517 \mathrm{~nm}$ using a microplate reader (SpectraMax i3; Molecular devices, USA).

\section{ABTS Radical Scavenging Assay}

ABTS radical scavenging assay was performed as previously described (Lee et al., 2018). ABTS (7 mM) stock solution with $2.45 \mu \mathrm{M}$ potassium persulfate was prepared and stored in the dark at room temperature for $12-16 \mathrm{~h}$ before use. The solution was diluted in PBS and equilibrated to obtain an absorbance of 0.700 at $734 \mathrm{~nm} .0 .2 \mathrm{~mL}$ of the sample and blank were mixed with $0.8 \mathrm{~mL}$ of ABTS solution. Finally, the absorbance was measured at $734 \mathrm{~nm}$ in a microplate reader (SpectraMax i3; Molecular devices, USA) against a blank after a 5 min of reaction time at room temperature.

\section{Ferric Reducing Antioxidant Power (FRAP) Assay}

Ferric reducing antioxidant power of extract was determined using the method previously described (Lee et al., 2018). Firstly, Diphylleia grayi extract was mixed with $0.2 \mathrm{M}$ sodium phosphate buffer ( $\mathrm{pH}$ 6.6) and $1 \%$ potassium ferricyanide. The 
mixture was incubated at $50^{\circ} \mathrm{C}$ for $20 \mathrm{~min}$. After that, $10 \%$ trichloroacetic acid $(2.5 \mathrm{~mL})$ was then added to stop the reaction and centrifuged at 3,000 $\mathrm{g}$ for $10 \mathrm{~min}$. The supernatant was collected and mixed with distilled water and $1 \%$ ferric chloride. The FRAP was measured at $700 \mathrm{~nm}$ using a microplate reader (SpectraMax i3; Molecular devices, USA).

\section{Intracellular ROS Detection}

Intracellular ROS was detected using DCF-DA fluorescence. Cells were incubated with $10 \mathrm{mM}$ AAPH for $1 \mathrm{~h}$ in the presence or absence of sample, and then stained with $10 \mu \mathrm{M}$ DCF-DA solution for $15 \mathrm{~min}$. After that, the cells were washed with PBS and DCF-DA fluorescence was detected by fluorescence microplate reader (SpectraMax i3; Molecular devices, USA) with excitation and emission of $495 \mathrm{~nm}$ and $529 \mathrm{~nm}$, respectively.

\section{In vitro tyrosinase Inhibition Assay}

Tyrosinase inhibition assay was performed as previously described (Lee et al., 2018). L-Tyrosine was used as substrate. The reaction mixture consisted of $0.1 \mathrm{M}$ Sodium phosphate buffer ( $\mathrm{pH}$ 6.5), purified mushroom tyrosinase and the sample. After adding $1.5 \mathrm{mM}$ of L-Tyrosin solution, incubate 10-15 $\min$ at $37^{\circ} \mathrm{C}$. The tyrosinase inhibition activity was measured at $490 \mathrm{~nm}$ using a microplate reader (SpectraMax i3; Molecular devices, USA).

\section{In vitro DOPA oxidation inhibition assay}

The reaction mixture is consisted of $0.1 \mathrm{M}$ sodium phosphate buffer ( $\mathrm{pH}$ 7.0), purified mushroom tyrosinase and the sample. After adding $0.06 \mathrm{mM}$ of L-DOPA solution, in vitro DOPA oxidation inhibition was measured at $475 \mathrm{~nm}$ using a microplate reader (SpectraMax i3; Molecular devices, USA).

\section{Collagenase inhibition assay}

Collagenase inhibition assay was performed as previously described (Jiang et al., 2007). 1mg of azo dye-impregnated collagen was washed twice with PBS. After then, mix with $800 \mu \mathrm{L}$ of $0.1 \mathrm{M}$ Tris-HCl (pH 7.0), $100 \mu \mathrm{L}$ of 200 units $/ \mathrm{mL}$ collagenase (stock solution), and $100 \mu \mathrm{L}$ sample and incubated at $37^{\circ} \mathrm{C}$. After $1 \mathrm{~h}$ incubating, the reaction mixture was centrifuged at $3000 \mathrm{rpm}$ for $10 \mathrm{~min}$ and the absorbance of the supernatant was detected at $550 \mathrm{~nm}$ using a microplate reader (SpectraMax i3; Molecular devices, USA).

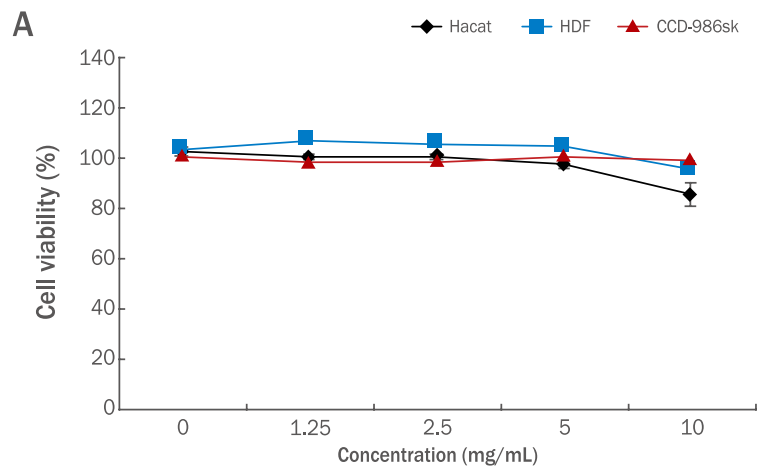

Figure 1. Cytotoxicity of Diphylleia grayi extract.

Cell viability of the Diphylleia grayi extract on normal skin cells.

\section{Statistical Analysis}

All experiments in this study performed more than three times and were presented as average values. Statistically significant was analyzed based on Student's $t$-test and determined to be statistically significant if the $p$ value was less than $0.05\left({ }^{*} p<0.05,{ }^{* *} p<0.01\right)$.

\section{Results and Discussion}

\section{Cytotoxicity of Diphylleia grayi extract}

Because cosmetic products are daily exposed to skin, it is important to check the cytotoxicity of ingredients of cosmetics. We investigated the cytotoxicity of Diphylleia grayi extract through the MTT assay on normal skin cells. We found that Diphylleia grayi extract dose not reduced cell viabilities, even at high dose $(10 \mathrm{mg} / \mathrm{mL}$ ) (Figure 1). Based on this result, we evaluated the cosmetic effectiveness below the concentration of $10 \mathrm{mg} / \mathrm{mL}$.

\section{Antioxidant activities of Diphylleia grayi extract}

Oxidative stress in skin plays a major role in aging process. The oxidative stress is generated by reactive oxygen species that can cause significant damage to biomolecules and it leads to disruption of skin barrier and wrinkle formation (Rinnerthaler et al., 2015). Hence, natural products which have antioxidant properties used many in cosmetic formulation to expect the prevention effect of skin aging. Here, we investigated the antioxidant activities of Diphylleia grayi extract through DPPH, ABTS radical scaveneging assay and FRAP assay and 
A
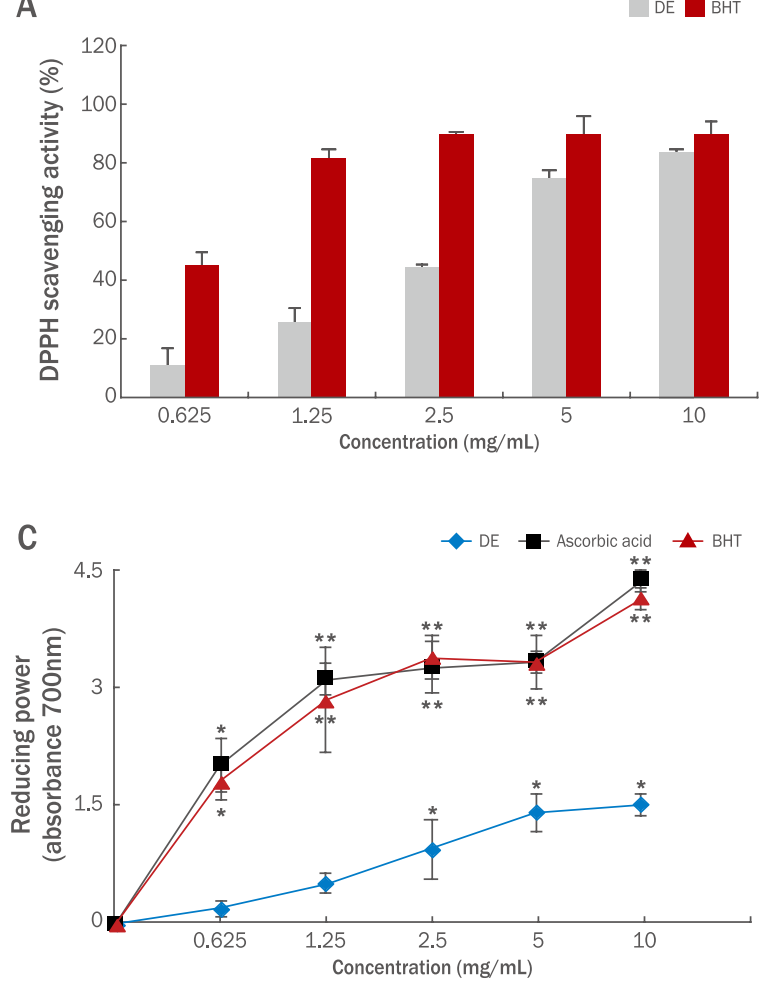

B

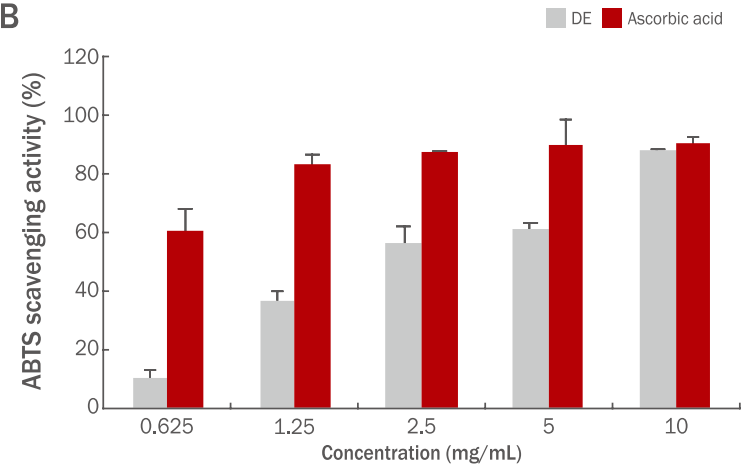

D

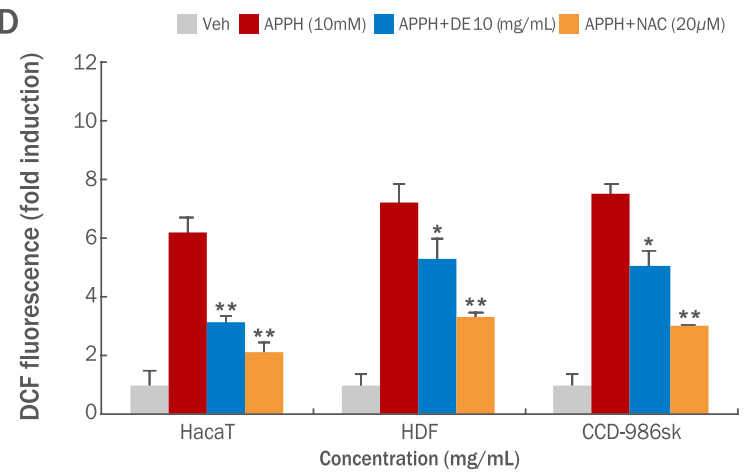

Figure 2. Antioxidant effects of Diphylleia grayi extract.

(A) DPPH radical scavenging activity of Diphylleia grayi extract. (B) ABTS radical scavenging activity of Diphylleia grayi extract. (C) FRAP reducing activity of Diphylleia grayi extract. (D) The intracellular ROS levels in AAPH-treated normal skin cells in a presence of Diphylleia grayi extract. DE, Diphylleia grayi extract. The Student's $t$-test was performed to determine statistical significance $\left({ }^{*} p<0.05,{ }^{* *} p<0.01\right)$.

the results are shown at figure 2 . The Diphylleia grayi extract could effectively decrease DPPH and ABTS radical in a dose dependent manner. The Diphylleia grayi extract showed $84.21 \%$ $\mathrm{DPPH}$ radical scavenging activity at $10 \mathrm{mg} / \mathrm{mL}$. ABTS radical scavenging activity of the Diphylleia grayi extract was shown $88.21 \%$ at $10 \mathrm{mg} / \mathrm{mL}$. These radical scavenging effects of the Diphylleia grayi extract were equivalent to those of similar to those of as positive controls (ascorbic acid and BHT). It is shown the $\mathrm{IC}_{50}$ values of $\mathrm{DPPH}$, ABTS assay in Table 1. FRAP reducing activity of the Diphylleia grayi extract was increased in a concentration dependent manner, but it was not as powerful as positive controls.

We further investigated whether the Diphylleia grayi extract could reduce intracellular ROS in skin cells using DCFDA fluorescence. The oxidative stress model was followed as previously reported. The ROS was induced by 2,2-azobis (2-amidinopropane) dihydrochloride (AAPH) and the intracellular ROS was measured in a presence of Diphylleia grayi extract. The Diphylleia grayi extract was significantly reduced the oxidative stress in human normal skin cell.

Table 1. Antioxidant activities of Diphylleia grayi extract ( $\left(\mathrm{IC}_{50}\right.$ value)

\begin{tabular}{lcc}
\hline \multirow{2}{*}{ Samples } & \multicolumn{2}{c}{$\mathrm{IC}_{50}$ value $(\mathrm{mg} / \mathrm{mL})$} \\
\cline { 2 - 3 } Diphylleia grayi extract & DPPH scavenging & ABTS scavenging \\
BHT & $3.23 \pm 0.13^{* *}$ & $3.42 \pm 0.35^{* *}$ \\
Ascorbic acid & $0.72 \pm 0.02^{* *}$ & - \\
\hline
\end{tabular}

Data are means \pm S.D. of 3 experiments. ${ }^{* *} p<0.01$ significantly different as compared to negative control group. DPPH, 2,2-diphenyl-1-(2,4,6trinitrophenyl)-hydrazinyl. ABTS, 2,2'-azino-bis(3-ethylbenzothiazoline-6-sulfonic acid. 

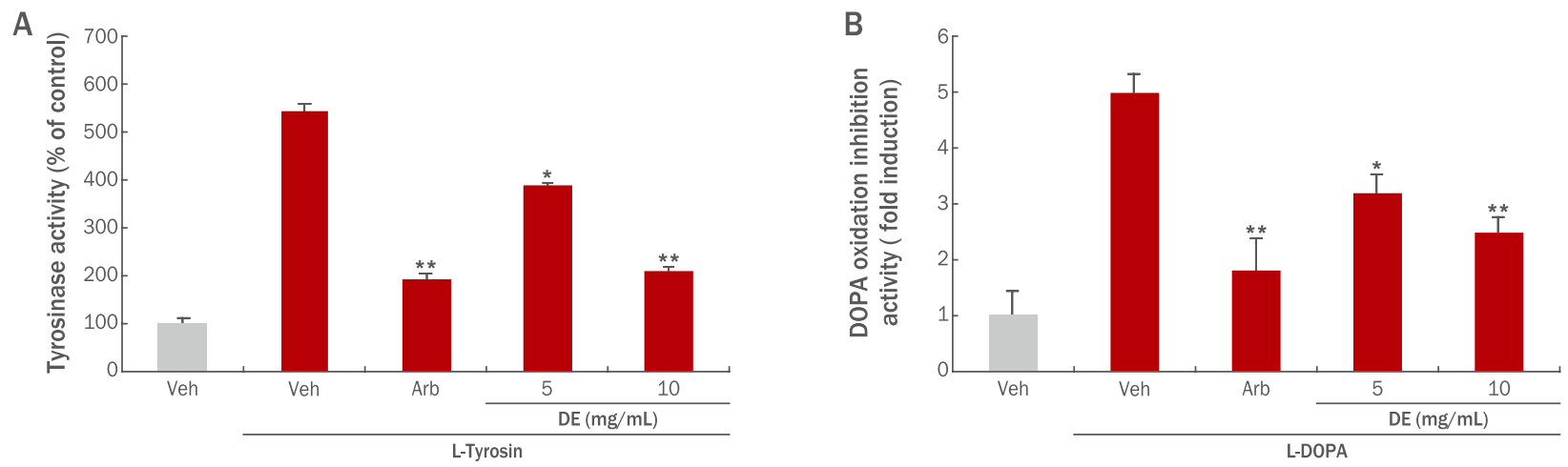

Figure 3. Whitening effects of Diphylleia grayi extract.

(A) In vitro tyrosinase inhibition activity of Diphylleia grayi extract (B) In vitro DOPA oxidation inhibition activity of Diphylleia grayi extract. Veh, vehicle, Arb, arbutin $(200 \mu \mathrm{g} / \mathrm{mL})$, DE, Diphylleia grayi extract. The Student's $t$-test was performed to determine statistical significance $\left({ }^{*} p<0.05,{ }^{* *} p<0.01\right)$.

Together, the Diphylleia grayi extract has strong antioxidant activity at the intracellular and extracellular conditions.

\section{Whitening effects of Diphylleia grayi extract}

Tyrosinase is a key enzyme, which catalyzes a rate-limiting step of the melanin synthesis. During the melanogenesis, L-tyrosine and L-DOPA served as substrates of the tyrosinase and they are oxidated to 3,4 dihydroxyphenylalanine (L-DOPA) and DOPAquinone (Shim, 2019). Therefore, inhibition of tyrosinase activity is the most prominent approach for the development of melanogenesis inhibitors (Pillaiyar et al., 2017). In fact, it is well researched that natural products have activities of tyrosinase inhibition. Here, we investigated the whitening effect of Diphylleia grayi extract through the in vitro tyrosinase inhibition assay and in vitro DOPA oxidation inhibition assay and the results are shown at Figure 3. We found that the Diphylleia grayi extract inhibited tyrosinase activity at over 5 $\mathrm{mg} / \mathrm{mL}$ concentration and also decreased L-DOPA oxidation rate. The whitening effect of Diphylleia grayi extract appear to related its antioxidant activities. Indeed, it is well researched natural antioxidants have anti-melanogenic activities. Based on these results, we found that Diphylleia grayi extract has skin whitening effect.

\section{Collagenase inhibition activity of Diphylleia grayi extract}

Collagen is a fibrous protein of conjunctive and connective tissues in the human body. Besides maintaining the skin structure, collagen establishes elasticity and keeps moisture in the skin (Aguirre-Cruz et al., 2020; Kim et al., 2020). Therefore, preventing collagen disruption is considered an effective way to conserve younger skin in cosmetic industries. Collagenase is responsible for cleavage of collagen and is necessary for remodeling of the extracellular matrix and facilitating the migration of keratinocytes, especially in injured skin (Rohani \& Parks, 2015). However, the induction of collagenase by UV light is considered the major reason of photo-aging in the skin (Pittayapruek et al., 2016). Here, we investigated collagenase inhibition activity of Diphylleia grayi extract using the azo dye-impregnated collagen and collagenase from Clostridium histolyticum. As shown in Figure 4, addition of increased concentration of Diphylleia grayi extract resulted in decreased collagenase activity. The collagenase inhibition activity was measured $45.31 \%$ at $10 \mathrm{mg} / \mathrm{mL}$ of Diphylleia grayi extract.

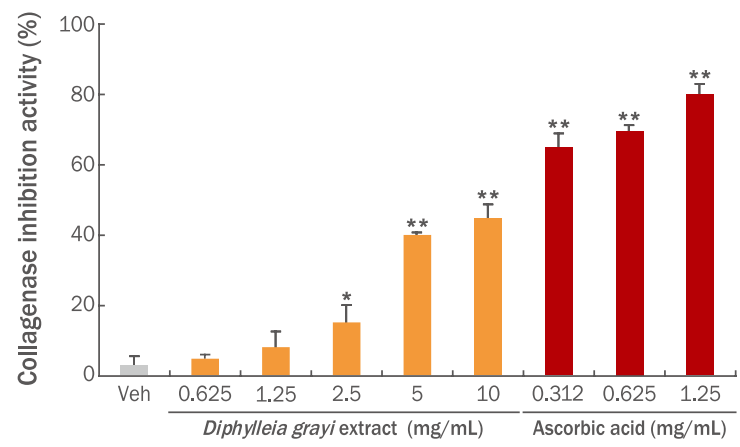

Figure 4. Anti-collagenase effects of Diphylleia grayi extract. Collagenase inhibition activity of Diphylleia grayi extract. The Student's $t$-test was performed to determine statistical significance $\left({ }^{*} p<0.05,{ }^{* *} p<0.01\right)$. 


\section{Conclusion}

It is well researched that "intrinsic" and "extrinsic" factors results in skin aging (Ryu et al., 2019). The intrinsic skin aging is genetically determined process that generated by naturally occurring free radicals and hormonal changes. On the other hand the extrinsic skin aging is caused by exogenous environment damaging factor such as, UV light, various pollutions (Farage et al., 2008). The extrinsic damaging factor triggers the production of ROS and it is considered the major reason of skin aging (Poljšak et al., 2012). Unlike intrinsic skin aging, extrinsic skin aging could be regulated through the inhibition of oxidative stress so that it has continuously researched to find effective antioxidants in cosmetic industries (Zhang et al., 2018). In this study, we firstly report the antioxidant effect and cosmetic effectiveness of the Diphylleia grayi extract. Through the ROS scavenging activity assays (DPPH, ABTS, FRAP) and measuring the oxidative stress reducing effect on skin cells, it has been found that Diphylleia grayi extract has strong antioxidant activities. In conjunction with these antioxidant properties of Diphylleia grayi extract, we found that Diphylleia grayi extract has the effect of inhibiting tyrosinase and collagenase activity. Taken together, Diphylleia grayi extract was identified as a promising natural cosmetic ingredient which has antioxidant, whitening and anti-wrinkle properties.

\section{Acknowledgements}

This study was supported by a grant "Hankook Cosmetics Manufacturing Co., Ltd."

\section{Author's contribution}

GL designed all experimental investigations. GL, AY and CP collected all data of this manuscript. MSJ and GYL assisted with experimental design. GL oversaw the project, and contributed to all aspects of analysis and experimental design. GL wrote the manuscript with assistance from AY and $\mathrm{CP}$.

\section{Author details}

Gibok Lee (Assistant Research Engineer), R\&D center, Hankook Cosmetics Manufacturing Co., Ltd., 35 Cheonggyecheon-ro, Jongno-gu, Seoul 03188, Korea;
Areum Yeom (Research Engineer), R\&D center, Hankook Cosmetics Manufacturing Co., Ltd., 35 Cheonggyecheonro, Jongno-gu, Seoul 03188, Korea; Chang-Min Park (Principal Research Engineer), R\&D center, Hankook Cosmetics Manufacturing Co., Ltd., 35 Cheonggyecheon-ro, Jongno-gu, Seoul 03188, Korea; Min-Seok Joung (General manager), R\&D center, Hankook Cosmetics Manufacturing Co., Ltd., 35 Cheonggyecheon-ro, Jongno-gu, Seoul 03188, Korea; Gi Yong Lee (Chief Research Officer), R\&D center, Hankook Cosmetics Manufacturing Co., Ltd., 35 Cheonggyecheon-ro, Jongno-gu, Seoul 03188, Korea.

\section{References}

Aguirre-Cruz G, León-López A, Cruz-Gómez V, JiménezAlvarado R, Aguirre-Álvarez G. Collagen hydrolysates for skin protection: oral administration and topical formulation. Antioxidants, 9: 181, 2020.

Brenner M, Hearing V. The protective role of melanin against UV damage in human skin. Photochemistry and Photobiology, 84: 539-549, 2007.

Broomhead AJ, Dewick PM. Tumour-inhibitory aryltetralin lignans in Podophyllum versipelle, Diphylleia cymosa and Diphylleia grayi. Phytochemistry, 29: 3831-3837, 1990.

Denat L, Kadekaro AL, Marrot L, Leachman SA, Abdel-Malek ZA. Melanocytes as instigators and victims of oxidative stress. Journal of Investigative Dermatology, 134: 15121518, 2014.

Farage MA, Miller KW, Elsner P, Maibach HI. Intrinsic and extrinsic factors in skin ageing: a review. International Journal of Cosmetic Science, 30: 87-95, 2008.

Jiang N, Tan N, Ho B, Ding JL. Azocoll protease activity assay. Protocol Exchange, 2007.

Shim JH. Whitening effect of brazilin in B16F10 cells. Asian Journal of Beauty and Cosmetology, 17: 287-294, 2019.

Krutmann J, Bouloc A, Sore G, Bernard B, Passeron T. The skin aging exposome. Journal of Dermatological Science, 85: 152-161, 2017.

Kim KS. Scalp improvement cosmetics' natural substance development trend: focused on plant extracts and marine life. Journal of Investigative Cosmetology, 16: 139-147, 2020. 
Kim HB, Kim JY, An Sk, Lee YJ, Cho DH, Kim HS, Bae Sh. Potential anti-wrinkle activity of Chlorella sp. HS1-derived oil components on human dermal fibroblasts. Asian Journal of Beauty and Cosmetology, 18: 41-51, 2020.

Lee G, Yeom A, Kim D, Park C, Joung M, Lee GY, Joeng C. Evaluation of Alcea rosea L. callus extract as a natural cosmetic ingredient. Journal of Society of Cosmetic Scientists of Korea, 3: 295-302, 2018.

Pittayapruek P, Meephansan J, Prapapan O, Komine $\mathrm{M}$, Ohtsuki M. Role of matrix metalloproteinases in photoaging and photocarcinogenesis. International Journal of Molecular Sciences, 17: 868, 2016.

Pillaiyar T, Manickam M, Namasivayam V. Skin whitening agents: medicinal chemistry perspective of tyrosinase inhibitors. Journal of Enzyme Inhibition and Medicinal Chemistry, 32: 403-425, 2017.

Poljšak B, Dahmane R. Free radicals and extrinsic skin aging. Dermatology Research and Practice, 2012: 135206, 2012.

Rinnerthaler M, Bischof J, Streubel MK, Trost A, Richter K. Oxidative stress in aging human skin. Biomolecules, 5:
545-589, 2015.

Ribeiro A, Estanqueiro M, Oliveira M, Sousa Lobo J. Main benefits and applicability of plant extracts in skin care products. Cosmetics, 2: 48-65, 2015.

Rohani M, Parks WC. Matrix remodeling by MMPs during wound repair. Matrix Biology, 44: 113-121, 2015.

Ryu JY, Rhie SJ, Lim KH, Choi YE, Han HS, Yang HO, Na EJ. Inhibitory effects of prunin on photo-aging in human keratinocytes (HaCaT) damaged by UVB radiation. Asian Journal of Beauty and Cosmetology, 17: 139-147, 2019.

Samson N, Fink B, Matts P. Interaction of skin color distribution and skin surface topography cues in the perception of female facial age and health. Journal of Cosmetic Dermatology, 10: 78-84, 2011.

Yong J, Chen F, Yang Q, Du G, Shan C, Bian H. Farooq, U, Hou $X$. Bioinspired transparent underwater superoleophobic and anti-oil surfaces. Journal of Materials Chemistry A, 3: 9379-9384, 2015.

Zhang S, Duan E. Fighting against skin aging. Cell Transplantation, 27: 729-738, 2018. 


\section{국문초록}

\section{Diphylleia grayi 추출물의 천연 화장품 원료로서의 생리활성 효능 평가}

이기복*, 염아름, 박창민, 정민석, 이기용

(주한국화장품제조 기술개발연구소, 서울, 한국

목적: 본 논문은 Diphylleia grayi 추출물의 천연 화장품 소재로서의 생리활성효능을 평가하기 위해 수행 되었다. 방법: Diphylleia grayi 추출물의 항산화 효능을 평가하기 위해 DPPH, ABTS, FRAP 법을 수행하였다. 그리고, Diphylleia grayi 추출물의 세포 내 산 화적 스트레스 감소 효과를 확인 하기 위하여 DCF-DA 형광을 이용하여 항산화 능력을 평가 하였다. 더불어 Diphylleia grayi 추출 물의 미백 및 항주름 효능을 확인하고자 타이로시나아제와 콜라게나아제 활성 저해 실험을 수행하였다. 결과: Diphylleia grayi 추출 물은 $\mathrm{DPPH}$ 와 $\mathrm{ABTS}$ 라디칼을 소거하는 강한 항산화 능력을 보였으며, 세포 내에서 발생하는 산화적 스트레스를 효과적으로 감소 시켰다. 게다가, 세포독성이 없는 농도에서 타이로시나아제와 콜라게나아제의 활성을 저해함이 확인 되었다. 결론: 본 연구 결과를 종합하여, Diphylleia grayi 추출물은 항산화, 미백, 항주름 효능을 가진 천연화장품 소재임이 확인되었다.

핵심어: Diphylleia grayi 추출물, ROS, 항산화, 타이로시나아제, 콜라게나아제

This study was supported by a grant "Hankook Cosmetics Manufacturing Co., Ltd."

\section{참고문헌}

김경숙. 두피개선 화장품의 천연소재 개발 동향:식물추출물과 해양생물을 중심으로. 대한미용학회지, $16: 139-147$, 2020.

김혜빈, 김지예, 안성관, 이용재, 조대현, 김희식, 배승희. 인간 진피섬유아세포에서 Chlorella sp. HS1 유래 오일의 콜라 겐 발현 증가 효력에 관한 연구. 아시안뷰티화장품학술지, 18: 41-51, 2020.

류지영, 이승자, 임계화, 최영은, 한효선, 양현옥, 나은주. Prunin의 자외선 B에 의해 손상된 인간 각질형성세포 (HaCaT) 에 대한 광노화 억제 효과. 아시안뷰티화장품학술지, 17: 139-147, 2019.

심중현. B16F10 세포에서 브라질린의 미백 효능. 아시안뷰티화장품학술지, 17: 287-294, 2019.

이기복, 염아름, 김동원, 박창민, 정민석, 이기용, 정철승. 접시꽃 캘러스 추출물의 천연화장품 원료로서의 효능평가. 대한 화장품학회지, 3: 295-302, 2018. 


\section{中文摘要}

\section{作为天然化妆品成分 Diphylleia grayi 提取物的生物活性评价}

李箕馥*，염아름，朴昌珉，鄭珉碩，李記龍

(株)韩国化妆品制造技术开发研究所，首尔，韩国

目的: 探索作为天然化妆品成分的Diphylleia grayi提取物的生物活性。方法: 采用DPPH法, ABTS清除法和 FRAP法测定Diphylleia grayi提取物的抗氧化活性。我们进一步研究了使用DCF-DA荧光法检测Diphylleia grayi 提取物是否能减少细胞内ROS。为了研究增白效果, 进行了酪氨酸酶抑制测定和L-DOPA氧化抑制测定。此外, 进行了胶原酶抑制试验，以评价白花前胡提取物的抗坡活性。结果: Diphylleia grayi提取物对DPPH, ABTS 自由基清除试验具有较强的抗氧化活性。此外，Diphylleia grayi提取物减少皮肤正常细胞上的细胞内ROS。 Diphylleia grayi 提取物还具有酪氨酸酶, L-DOPA氧化和胶原酶的抑制活性。结论: 因此, Diphylleia grayi 提 取物被鉴定为具有抗氧化，增白和抗波特性的有前途的天然化妆品成分。

关键词: Diphylleia grayi，活性氧，抗氧化剂，酪氨酸酶，胶原酶 
